\title{
Assessment of the anti-Salmonella activity of commercial formulations of organic acid products
}

Andrew Wales, lan McLaren, André Rabie, Rebecca J. Gosling, Francesca Martelli*, Robin Sayers and Robert Davies

Department of Bacteriology and Food Safety, Animal Health and Veterinary Laboratories Agency, Woodham Lane, New Haw, Addlestone, Surrey KT15 3NB, United Kingdom.

*Author for correspondence:

Francesca Martelli Department of Bacteriology and Food Safety, Animal Health and Veterinary Laboratories Agency, Woodham Lane, New Haw, Addlestone, Surrey, KT15 3NB, UK.

Email: $\quad$ Francesca.Martelli@ahvla.gsi.gov.uk

Tel: $\quad$ +44 $\quad$ + $\quad$ 1932357058

Fax: $\quad$ +441932357595

Short title: anti-Salmonella activity of organic acid products

Keywords: Salmonella, organic acid, poultry

This is an Accepted Manuscript of an article published by Taylor \& Francis in Avian Pathology on $22^{\text {nd }}$ April 2013, available online:

http://www.tandfonline.com/10.1080/03079457.2013.782097 


\begin{abstract}
Organic acid products are widely used in the United Kingdom poultry industry as feed or water additives. Claims for Salmonella control are made for some of these products, but there are few studies comparing the anti-Salmonella effect of the various products in tests that reflect field application. The present studies examined the effects of thirteen commercial blends (four water and nine feed products) on Salmonella Enteritidis and Typhimurium strains. Initial screening, in nutrient broth, of all products with all strains, revealed little variation between strains in respect of maximum inhibitory and bactericidal dilutions of each product. However, between the products there was wide and significant variation in the maximum inhibitory and bactericidal dilutions, spanning a 700-fold range in the case of bactericidal dilutions for feed-associated products.
\end{abstract}

Further tests were performed, examining reductions in inoculated Salmonella numbers in various matrices (water, feed, soiled litter, crop and caecal contents) following the addition of the products at recommended inclusion rates. One product, incorporating formaldehyde in addition to organic acid, was consistently most active in all matrices, exceeding reductions associated with other products by one to three log units at most time points. Many products showed only modest anti-Salmonella activity, amounting to zero or one log unit above negative controls at many time points, and the most active products were not the same in all matrices. Tap water appeared to enhance the ability of products to reduce Salmonella, in comparison with bottled mineral or river water. 


\section{Introduction}

Organic acid (OA) products are used extensively in the poultry sector, typically as blends of acids and their salts, but sometimes with other constituents also. They are marketed as additives for drinking water or feed, with claims that include: improving feed or water hygiene, improving digestive health and efficiency, and combating specific pathogens such as Salmonella and Campylobacter. Of various acidic organic products, the carboxylic acids are attractive as antimicrobial compounds in foodproducing animals to reduce the need for preventive medication or treatment with antibiotics, as they are a feature of normal metabolism and gut environment and thus do not generally pose an issue of residues in food.

The antibacterial activity of carboxylic OAs is believed to derive from their ability to cross bacterial membranes and, once in the cytoplasm, to dissociate into protons and organic anions and interfere with $\mathrm{pH}$ homeostasis (proton effect) and other important cell features including membrane structure, osmolarity and macromolecule synthesis (anion effects) (Cherrington et al., 1990; Russell, 1992; Ricke, 2003; van Immerseel et al., 2006). OA molecules differ in carbon chain lengths and in the number and nature of attached acid and other chemical groups. Studies over several years have yielded conflicting findings regarding the relative antiSalmonella potencies of different OAs, possibly because of the many different conditions (for example moisture, $\mathrm{pH}$, and bacterial physiological states) that may affect measurements (Wales et al., 2010).

Because efficient penetration of bacterial cells occurs when OA molecules are in an electrically neutral, undissociated state, their activity is considerably enhanced in acidic environments, when most weak acid molecules are undissociated (Ricke, 2003). Inclusion rates (generally two to three percent) that depress $\mathrm{pH}$ sufficiently for this effect to occur in feed cause unacceptable problems including unpalatability and corrosion, and are generally reserved for treating feed ingredients prior to compounding (Pinchasov \& Jensen, 1989; Adams, 1991). There is some evidence that poultry may show side effects of certain OAs at lower inclusion rates than other 
livestock (EFSA, 2011). Thus, OAs and their salts are added at low inclusion rates (generally less than one percent) to feed and water for poultry, and much of the antibacterial effect may be exerted in the first low pH environment encountered, i.e. the foregut. This theoretically can also protect birds ingesting Salmonella from other sources whilst they are consuming OA-treated feed or water.

In addition to the above effects, certain short- and medium-chain OAs will inhibit the invasion of epithelial cells by Salmonella, even when present below minimum inhibitory concentrations for the organism. Butyric acid in particular has been found to suppress expression of Salmonella virulence proteins (van Immerseel et al., 2006) and to induce defence peptides in poultry (Sunkara et al., 2011). Feeding low concentrations $(0.1 \%$ to $0.2 \%)$ of butyric acid, stabilised to maximise large intestinal concentrations to poultry had a suppressive effect on caecal colonisation and/or the level of excretion of Salmonella following oral exposure (van Immerseel et al., 2004, 2005; Fernandez-Rubio et al., 2009). This type of effect is quite specific to the acid being used, as stabilised acetic and formic acids appear to promote Salmonella virulence at low concentrations (van Immerseel et al., 2004).

Much of the antimicrobial effect of OA products is claimed to arise from synergism between elements in the blend. However, data regarding the efficacy against Salmonella of various commercial formulations, if available, is based on nonstandardised tests that may not replicate conditions of use in the field. There is a need to develop a validated assay procedure to guide decisions regarding the efficacy of such products. The main aim of the present in vitro tests was to screen a number of commercial preparations for comparative efficacy, first in the medium (water or feed matrix) for which they are marketed, and then in simulated postingestion and post-excretion environments of crop contents, caecal contents and litter. 


\section{Materials and methods}

Selection of strains and products. Salmonella strains (Table 1) included representative field strains of current or emerging significance for UK egg production, plus two vaccine strains. The field strains were six recent (years 2006 to 2010) isolates from various laying farms, two isolated after on-farm treatment of feed and water, respectively, with an OA product. One other strain showed greater invasion in an in vitro organ culture test. Two field strains were S. Typhimurium-like monophasic serovars. The vaccine strains were cell wall-deficient and were suspected to be more highly sensitive to the effects of OAs.

The OA products tested (Table 2) were selected on the basis of their frequency of use in the UK poultry industry, as reported by poultry veterinarians, and interest in particular new products.

Bacteriological procedures. Stationary phase broth culture for inoculation of matrices was prepared by aerobic incubation of Salmonella Enteritidis (SE) overnight at $37^{\circ} \mathrm{C}$ in Nutrient Broth No. 2 (Oxoid Ltd.), then at room temperature for a further $24 \mathrm{~h}$. The culture was serially diluted in quarter-strength Ringer's solution to create a hundred-fold dilution for inoculation. Each culture preparation was enumerated by spread-plating.

Enumeration of surviving Salmonella from matrix tests was accomplished using a modified most probable number based semi-quantitative technique, as previously described (Wales et al., 2006). Briefly, an initial five- or ten-fold dilution of the recovered material was made in buffered peptone water (BPW; Oxoid Ltd.) and a sequential dilution series through seven decimal stages was created immediately in BPW. For the water matrix the initial sample aliquot was $1 \mathrm{ml}$ but for the composite matrices the size was $5 \mathrm{~g}$, to ensure a representative sample and good dispersal. An initial ten-fold dilution of the $5 \mathrm{~g}$ sample proved difficult, given the container sizes readily available, so for later experiments a five-fold initial dilution was used. Dilutions were pre-enriched by incubation overnight and then $0.1 \mathrm{ml}$ was plated 
onto modified semi-solid Rappaport-Vassiliadis (MSRV; Oxoid Ltd.) enrichment agar. Spreading growth on MSRV was subcultured onto Rambach (CHROMagar) indicator agar.

Initial screening of strains and products for maximum inhibitory and maximum bactericidal dilutions.

Maximum inhibitory dilution (MID). For each Salmonella strain to be screened, dilution series of each OA product in Nutrient Broth No.2 were prepared in 96-well microtitre plates. For starting dilutions, $1 \mathrm{~g}$ of powder or $1 \mathrm{ml}$ of liquid product was added to $24 \mathrm{ml}$ sterile distilled water. Powders were dissolved in cold or warm water, depending on their solubility. Every microtitre well was prepared with $75 \mu \mathrm{l}$ of broth then, for each product, $75 \mu \mathrm{l}$ of the 1:25 starting dilution was added to the first well in a row. A doubling dilution series from 1:50 to 1:25,600 was created by sequential transfer of $75 \mu$ l between 10 adjacent wells. Two control wells at the end of each row of 12 contained Nutrient Broth only. An aliquot $(7.5 \mu \mathrm{l})$ of a broth culture of the test Salmonella strain $\left(37^{\circ} \mathrm{C}\right.$, in Nutrient Broth no. 2, incubated aerobically overnight without shaking) diluted 1:100 in Nutrient Broth no. 2 was added to every well except the twelfth in each row. Plates were incubated $\left(37^{\circ} \mathrm{C}, 18 \mathrm{~h}\right)$ and bacterial growth in each well was then determined by the presence of visible turbidity. The highest dilution without visible turbidity was recorded as the MID.

Maximum bactericidal dilution (MBD). The MBD was then determined by taking a $10 \mu \mathrm{l}$ aliquot from each well showing no turbidity and adding it to $190 \mu \mathrm{l}$ of Nutrient Broth no. 2 in a corresponding well on a new microtitre plate, then incubating the new plate and examining it for bacterial growth as previously. The highest original dilution showing no growth after the second dilution and incubation steps was recorded as the MBD. One to four tests were done per product with each Salmonella strain.

Performance of products in matrices. In matrix tests, a single Salmonella Enteritidis (SE) strain (S9549/07) was used and products were applied at manufacturers' maximum recommended concentrations. Products marketed for water were tested 
in water matrices and in caecal and crop contents; those marketed for feed were tested in all matrices except water. For negative controls, products were either omitted (water matrices) or replaced by an equivalent volume or mass (depending on the physical form of the product) of sterile water (other matrices). Quarterstrength Ringer's solution was added to some matrices in order to facilitate mixing and dispersal of products and SE inoculum.

Water matrix. Each product was dissolved and mixed thoroughly in $100 \mathrm{ml}$ tap water or river water and the $\mathrm{pH}$ was measured with a handheld meter. Stationary-phase broth culture $(1 \mathrm{ml})$ was added to each flask, with thorough mixing. The test mixes were held at room temperature $\left(18^{\circ} \mathrm{C}\right)$. Aliquots $(1 \mathrm{ml})$ were withdrawn after 1,2 and 4 hours and subjected to enumeration of surviving Salmonella. Follow-up studies were performed using the product that was associated with the most rapid and substantial reduction in Salmonella numbers in the initial tests. Differing temperatures (room temperature or waterbath at $18{ }^{\circ} \mathrm{C}$ or $4{ }^{\circ} \mathrm{C}$ ) and water types (tap water or 'Fairbourne Springs' supermarket bottled still mineral water) were used in these later studies. The mineral water was chosen as an example of unchlorinated water with minimal suspended solids. Its source and typical chemical content of the mineral water used is provided as a supplementary file.

Feed matrix. Mixed grain from a local supplier was ground using a kitchen blender until it resembled layer mash. This formulation did not contain added fats, oils, proteins or antimicrobial additives as may be found in compounded feed. Each OA product was added to $20 \mathrm{~g}$ of feed in a sterile $110 \mathrm{ml}$ tube, followed by diluted stationary-phase SE culture $(0.1 \mathrm{ml})$ with tumbling of the tubes on a rotator arm for 10 minutes after each step. The tubes were held at room temperature $\left(20-22^{\circ} \mathrm{C}\right)$ and $5 \mathrm{~g}$ samples were taken after 24 hours and seven days. These were dispersed in $45 \mathrm{ml} \mathrm{BPW}$ by soaking for two to three minutes followed by vortex mixing and the resulting suspensions were processed for enumeration.

Litter matrix. Soiled litter from a specified pathogen-free flock at the Animal Health and Veterinary Laboratories Agency (AHVLA) Weybridge site was vortex-mixed with 
quarter-strength Ringer's solution in a 1:2 ratio. OA preparations were added to $10 \mathrm{~g}$ samples of this, followed by $0.1 \mathrm{ml}$ of stationary-phase SE culture. The preparations were vortex-mixed, held at room temperature $\left(20\right.$ to $\left.22^{\circ} \mathrm{C}\right)$, and $5 \mathrm{~g}$ aliquots were taken after 4 and 8 hours. These were each mixed with $20 \mathrm{ml} \mathrm{BPW}$ and dilution series were then prepared for enumeration of Salmonella.

Caecal and crop matrices. The contents of both anatomical structures were collected from slaughtered small-scale commercial broilers and spent AHVLA layer hens. Caecal contents were used fresh, whilst crop contents were stored at $-80{ }^{\circ} \mathrm{C}$ then thawed before use. Both were mixed with quarter-strength Ringer's solution (crop at 1:1 ratio, caecum at 1:2). OA preparations were added to $20 \mathrm{~g}$ aliquots in tubes, which were incubated for $10 \mathrm{~min}$ at $41.5^{\circ} \mathrm{C}$ in a waterbath before $0.1 \mathrm{ml}$ stationaryphase SE culture was added. The $\mathrm{pH}$ of some crop content mixes was measured with a handheld meter and all preparations were vortex-mixed then incubated at $41.5^{\circ} \mathrm{C}$. After various time intervals, $5 \mathrm{~g}$ aliquots were taken, mixed with $20 \mathrm{ml} \mathrm{BPW}$ and prepared for Salmonella enumeration.

Statistical analysis of maximum inhibitory and maximum bactericidal dilutions. The data were transformed according to the formula $y=\log _{2}(x / 25)$ so that the transformed dilution values of 50,100, 200 etc were $1,2,3$, etc. Dilutions of $<50$ were recorded as zero and these were regarded as lying in the interval 1 to 50 . In order to take account of the interval data, the interval regression model in STATA ('intreg') was used to fit main effects models, with strain and product as categorical variables. When either effect was significant at $p \leq 0.05$ the individual strains/products were compared with one another by Tukey's HSD test at a significance level of $p=0.05$, with adjustments made for the unequal variances of the predicted means. The predicted means were then transformed back to the original scale, i.e. $x=25\left(2^{y}\right)$. 


\section{Results}

Maximum inhibitory and bactericidal dilutions for Salmonella strains. The eight strains tested did not differ significantly in the predicted mean inhibitory or bactericidal dilutions of products, except in the case of mean bactericidal dilutions amongst products marketed for feed, where a significant difference $(p=0.024)$ was seen only between the most and least resistant strains.

Maximum inhibitory and bactericidal dilutions of organic acid products. Significant differences were seen amongst the four water-treatment products for both MID and MBD values (Table 3), with a wider range of predicted mean dilutions for the latter. One product (B) was most potent for both MID and MBD; similarly one product (A) was least potent in both tests. For the nine feed treatments, a wide range of predicted mean dilutions was seen for both MBD (7 to 4936) and MID (64 to 23,777; Table 3). The three least potent $(\mathrm{N}, \mathrm{O}, \mathrm{K})$ and the three most potent $(\mathrm{J}, \mathrm{H}, \mathrm{M})$ preparations occupied the same positions in the rank order for both MID and MBD. Significant differences in mean dilutions were seen, except among the lower-potency preparations.

\section{Matrices}

Viable Salmonella counts in inocula for the matrices ranged between 1.1 and 1.8 $\times 10^{7}$ cfu. $\mathrm{ml}^{-1}$.

Water matrix. There was an initial Salmonella concentration in the test flasks of approximately $1 \times 10^{5} \mathrm{cfu}_{\mathrm{ml}} \mathrm{m}^{-1}$. Four out of five products effected rapid reductions in viable Salmonella concentrations in tap water, but had substantially less effect in river water, despite starting $\mathrm{pH}$ values being similar to or lower than those in tap water (Table 4). The remaining water product (B) was associated with higher starting $\mathrm{pH}$ than any of the others, and was associated with much lesser reductions in Salmonella in tap water, but performed similarly to three other products in river water. 
In follow-up studies with product $\mathrm{D}$, starting $\mathrm{pH}$ values were in the ranges 3.4 to 3.6 for OA preparations, 7.1 to 7.7 for tap-water controls and 8.0 for the bottled water control. A lower temperature $\left(4^{\circ} \mathrm{C}\right.$ versus $\left.18{ }^{\circ} \mathrm{C}\right)$ was associated with a slower rate of inactivation of Salmonella (Figure 1). The tap-water controls showed substantial antiSalmonella activity, especially when in a stable, warmer $\left(18^{\circ} \mathrm{C}\right.$ waterbath) environment. Bottled water was associated with substantially less inactivation of Salmonella than was tap water (Figure 2) despite the initial pH values of both media, after addition of acid product, being very similar.

Feed and litter matrices. In initial experiments with feed matrix, reductions in Salmonella of between zero and three log units were observed after $24 \mathrm{~h}$ for 10 of the 11 products (Table 5). A maximum of one further log unit reduction was seen after six more days with these products. The remaining product (M) was associated with the most marked reduction by $24 \mathrm{~h}$, exceeding the 3 log unit quantification limit of the assay. Further studies were performed with the three products ( $E, F$ and $M)$ that had been associated with a two log unit or more reduction by $24 \mathrm{~h}$ in the initial test. These additional tests involved two repetitions, each with two subsamples processed on each sampling occasion. Reductions in Salmonella were similar to the previous experiments (data not shown), although there was also a measurable reduction in Salmonella (up to two log units by seven days) in the negative control preparations.

Results from tests using soiled litter are summarised in Table 5. Two products ( $L$ and M) were associated with greater reductions in Salmonella numbers than the other products.

Crop and caecal content matrices. In crop content, the most effective products (D, F, M) were associated with a reduction of at least five log units after an hour (Table 6, run a). In negative controls, Salmonella declined at a lesser rate, which was nonetheless substantial compared with control preparations in other matrices. With some products (for example I), a modest reduction in four hours was followed by much more substantial reduction (six log units or more) by eight hours. Four of the 
most effective products again performed similarly in replicate experiments (Table 6, run $\mathrm{b}$ ). In these, the $\mathrm{pH}$ of the crop contents was 4.7 to 4.8 before addition of product and $4.2,4.0,4.5$ and 3.3 after addition of products $D, E, F$ and $M$, respectively.

In incubated caecal content (Table 6), two of 14 products were associated with a Salmonella reduction of six log units or more by nine hours. With one (F), a progressive reduction was observed over time; with the other (M), a reduction of greater than six log units was evident by one hour. Other products were similar to the negative control in respect of Salmonella reductions.

\section{Discussion}

The efficacy that is seen in the field with OA products is rather variable and sometimes disappointing (Davies \& Carrique-Mas, 2010; Wales et al., 2010). The present studies aimed to explore the usefulness of tests to evaluate and compare OA products in conditions that mimic application in the field. In vivo effects of low concentrations of specific OAs (for example butyric acid) at epithelial surfaces in the large intestine were outside the scope of the study.

In an attempt to survey a wide range of products with the resources available, repetitions were generally only performed on those products that showed comparatively high efficacy in initial experiments. Given that some matrices were by their nature complex and non-uniform, it is notable that the findings were generally consistent, showing few aberrant results in sequential samples or repetitions.

The 'masking' of viable Salmonella cells owing to OAs depressing the $\mathrm{pH}$ of media in the culture-enumeration process, has been demonstrated (Carrique-Mas et al., 2007), wherein it was concluded that a formaldehyde/OA product demonstrated little masking in comparison with OA-only products. This effect potentially could have helped overstate the apparent efficacy of OAs in the present study. However, beyond an initial dilution of 1:5 or 1:10 in BPW, residual OA in the decimal dilution 
series would be so low as to be unlikely to have any practical $\mathrm{pH}$ effect on the media. Therefore masking wouldn't be likely to have helped overstate the effect of the preparations associated with low or moderate reductions (up to around 3 log units) in Salmonella counts.

Screening of eight stationary-phase Salmonella strains, varied in respect of serovar, virulence, source and recent exposure to OAs in the field, for inhibition and killing by the OA products revealed a modest spread of susceptibilities. Where there was most variation between strains (bactericidal activity of feed products), this amounted to little more than a four-fold range. Therefore, a single strain could be selected for further tests with some confidence that findings would be broadly applicable to other field strains.

By contrast, much greater variations in MID and MBD were observed between products. Only in the case of MID for water products did this spread appear to correlate with the manufacturers' recommended maximum concentrations. In the other cases these recommended working concentrations did not prove to be a reliable indicator of absolute or relative potency against Salmonella suspensions in culture medium. The most marked example is MBDs of feed products, where a 700fold range of predicted mean dilutions was seen, among products with a four-fold range of recommended working concentrations. Given that most of the products tested were not marketed for application to liquid media, and in many cases not specifically for Salmonella control, a wide range of potencies in an in vitro Salmonella suspension test is not surprising.

The bactericidal action of the products marketed for use in water proved to be greatly affected by the type of water in which they were dissolved. At recommended concentrations, their effect was attenuated in river water compared with tap water, an effect that might be associated with the influence of organic and mineral particulate matter, including the action of free-living bacteria, in the river water (Sawaya et al., 2008). However, when the most effective product (D) was compared 
in tap and bottled mineral water, a substantially higher, and $\mathrm{pH}$-independent, antiSalmonella activity was again seen with the tap water.

It is possible that there is significant synergy between acidifiers and residual chlorine in tap water, and the noticeable but variable anti-Salmonella effect observed in unmodified (control) tap water may be a pointer to a chlorine effect. Whatever the cause, the environmental anti-Salmonella effect of water acidifiers may be quite sensitive to the composition of water used, and on-farm trials may be required to establish efficacy in any particular application. Low temperature also reduced Salmonella killing, something which may be significant in colder seasons.

The control of Salmonella by OA products applied to drinking water or feed may be mediated to some extent by effects in the foregut, where low $\mathrm{pH}$ and endogenous (secreted and fermentative) acids add to, or synergise with, the bactericidal effect of exogenous products. The $\mathrm{pH}$ and retention times of feed in the chicken crop appear to be highly variable and heavily influenced by feed composition and feeding schedule (Svihus, 2010). Products in feed or water that can rapidly reduce the $\mathrm{pH}$ of the crop, and which are associated with rapid killing of ingested Salmonella, may be particularly well suited to protecting birds against ingested environmental Salmonella. In this regard, although heavy reductions in Salmonella numbers were seen eventually with all products, some products were only associated with modest reductions in counts after four hour's exposure in crop contents. Therefore, the eventual reductions seen after eight hours may in some cases have owed more to endogenous activity of the crop contents than to the added products, as control mixes of crop contents with water were associated with four log unit reductions and more by five to eight hours.

The feed matrix study found reductions in Salmonella of around one log unit after seven days. The products associated with greater reductions showed more substantial reductions much sooner, by 24 hours after incorporation. Examination of several replicate runs with these more active products confirmed their relative efficacies and demonstrated again that most reduction was seen up to $24 \mathrm{~h}$ after 
application in this model system. The incorporation rates used are not typically associated with a marked depression of $\mathrm{pH}$ in feed matrices (Wales et al., 2010), and therefore it is perhaps unsurprising that the anti-Salmonella effect was, in most cases, modest compared with the crop contents. It is also logical that a product (M) that has a non-acid bactericide (formaldehyde) as a major component should demonstrate comparatively high efficacy in this matrix.

However, one product that comprises medium-chain fatty acids (F) was, in both feed matrix trials, clearly associated with a more rapid and substantial reduction in Salmonella than the other acid-based products. This suggests that there is a significant bactericidal mechanism (or mechanisms) associated with this blend that does not depend on a low $\mathrm{pH}$. Indeed in caecal contents, another matrix that does not typically have a low $\mathrm{pH}$, this same product again showed a comparatively high level of anti-Salmonella activity. It may be that such activity is rather matrix-specific, as the same product did not (in common with most products) show a high level of activity in poultry litter, another non-acid matrix.

The consistency seen in results where repetitions were performed indicates that the fact that products did not appear to perform consistently from matrix to matrix was not a consequence of variation inherent in the experimental procedures. Moreover, one product (containing formaldehyde) was consistently associated with high levels of Salmonella inactivation in all matrices. It is therefore reasonable to surmise that there is indeed substantial, and unpredictable, variation between the antiSalmonella effects of OA products when applied at recommended inclusion rates to different matrices. This may be for reasons that can be inferred from the composition of the product, but in some cases the effect cannot at present be explained. Superior performance may be quite matrix-specific, and this phenomenon extends even to the source of water used in drinking systems.

Inconsistent effects of OA products on Salmonella in differing matrices may contribute to variable, and often disappointing, Salmonella control when these products are applied in the field. In addition to differences in the prevailing 
challenges to Salmonella control on any particular premises, realistic expectations of the contribution OA products can make to Salmonella control need to take account of this identified variability.

\section{Acknowledgement}

This work was funded by the UK Department of Food, Environment and Rural Affairs (Defra) as part of project OZ0332. 


\section{References}

Adams, C.A. (1991) A review of chemical treatment of raw materials and finished products in reducing pathogens. Feed Compounder, 11, 30-33.

Carrique-Mas, J.J., Bedford, S. \& Davies, R.H. (2007) Organic acid and formaldehyde treatment of animal feeds to control Salmonella: efficacy and masking during culture. Journal of Applied Microbiology, 103, 88-96.

Cherrington, C.A., Hinton, M. \& Chopra, I. (1990) Effect of short-chain organic acids on macromolecular synthesis in Escherichia coli. Journal of Applied Microbiology, $68,69-74$.

Davies, R.H. \& Carrique-Mas, J. (2010) Studies on the use of organic acids and competitive exclusion agents in commercial laying flocks infected with $S$. Enteritidis. I3S International Symposium "Salmonella and Salmonellosis". St Malo, France.

EFSA (2011) Scientific Opinion on the safety and efficacy of propionic acid, sodium propionate, calcium propionate and ammonium propionate for all animal species. EFSA Journal, 9, 2446.

Fernandez-Rubio, C., Ordonez, C., Abad-Gonzalez, J., Garcia-Gallego, A., Honrubia, M.P., Mallo, J.J. \& Balana-Fouce, R. (2009) Butyric acid-based feed additives help protect broiler chickens from Salmonella Enteritidis infection. Poultry Science, 88, 943-948.

Pinchasov, Y. \& Jensen, L.S. (1989) Effect of short-chain fatty acids on voluntary feed of broiler chicks. Poultry Science, 68, 1612-1618.

Ricke, S.C. (2003) Perspectives on the use of organic acids and short chain fatty acids as antimicrobials. Poultry Science, 82, 632-639.

Russell, J.B. (1992) Another explanation for the toxicity of fermentation acids at low $\mathrm{pH}$ : Anion accumulation versus uncoupling. Journal of Applied Bacteriology, 73, 363-370.

Sawaya, K., Kaneko, N., Fukushi, K. \& Yaguchi, J. (2008) Behaviors of physiologically active bacteria in water environment and chlorine disinfection. Water Science and Technology, 58, 1343-1348.

Sunkara, L.T., Achanta, M., Schreiber, N.B., Bommineni, Y.R., Dai, G., Jiang, W.Y., Lamont, S., Lillehoj, H.S., Beker, A., Teeter, R.G. \& Zhang, G.L. (2011) Butyrate enhances disease resistance of chickens by inducing antimicrobial host defense peptide gene expression. PLoS One, 6, 11. 
Svihus, B. (2010) Effect of digestive tract conditions, feed processing and ingredients on response to NSP enzymes. In M.R. Bedford \& G.G. Partridge (Eds.), Enzymes in Farm Animal Nutrition, 2nd edn. (pp. 129-159). Wallingford, UK: CABI.

Van Immerseel, F., Boyen, F., Gantois, I., Timbermont, L., Bohez, L., Pasmans, F., Haesebrouck, F. \& Ducatelle, R. (2005) Supplementation of coated butyric acid in the feed reduces colonization and shedding of Salmonella in poultry. Poultry Science, 84, 1851-1856.

van Immerseel, F., Fievez, V., Buck, J.d., Pasmans, F., Martel, A., Haesebrouck, F. \& Ducatelle, R. (2004) Microencapsulated short-chain fatty acids in feed modify colonization and invasion early after infection with Salmonella Enteritidis in young chickens. Poultry Science, 83, 69-74.

van Immerseel, F., Russell, J.B., Flythe, M.D., Gantois, I., Timbermont, L., Pasmans, F., Haesebrouck, F. \& Ducatelle, R. (2006) The use of organic acids to combat Salmonella in poultry: a mechanistic explanation of the efficacy. Avian Pathology, 35, 182-188.

Wales, A.D., Allen, V.M. \& Davies, R.H. (2010) Chemical treatment of animal feed and water for the control of Salmonella. Foodborne Pathogens and Disease, 7, 3-15.

Wales, A.D., Davies, R.H. \& Breslin, M. (2006) Assessment of cleaning and disinfection in Salmonella-contaminated poultry houses using qualitative and semi-quantitative culture techniques. Veterinary Microbiology, 116, 283-293. 


\section{Tables}

Table 1: Details of Salmonella strains screened for susceptibility to organic acid products in vitro

\begin{tabular}{|c|c|c|c|}
\hline Farm (strain) & Serovar $^{\mathrm{a}}$ & $\begin{array}{l}\text { Phage } \\
\text { Type }\end{array}$ & Comments \\
\hline$A(S 0814-10)$ & 4,12:i:- & 193 & Monophasic S. Typhimurium-like \\
\hline B (S1764-10) & 4,12:i:- & 193 & Monophasic S. Typhimurium-like \\
\hline C (S1887-06) & Enteritidis & 4 & SE invasive strain \\
\hline D (S2922-08) & Enteritidis & 4 & $\begin{array}{l}\text { Twelve days after use of acid } \\
\text { product }\end{array}$ \\
\hline E (S9549-07) & Enteritidis & 4 & Before use of acid product \\
\hline E (S3513-08) & Enteritidis & 4 & $\begin{array}{l}\text { Ten days after use of acid } \\
\text { product }\end{array}$ \\
\hline (Sm24/Rif12/Ssq) & Enteritidis & & AviPro Salmonella vaccine strain \\
\hline (Nal2/Rif9/Rtt) & Typhimurium & & AviPro Salmonella vaccine strain \\
\hline
\end{tabular}

a Serotyped at Animal Health and Veterinary Laboratories Agency Salmonella unit 
Table 2: Details of commercial organic acid products used

\begin{tabular}{|c|c|c|c|}
\hline Product & $\begin{array}{l}\text { Intended } \\
\text { use }\end{array}$ & $\begin{array}{l}\text { Maximum } \\
\text { concentration }^{a}\end{array}$ & $\begin{array}{l}\text { Form used in present study. Further } \\
\text { information / manufacturer's description }\end{array}$ \\
\hline A & $\begin{array}{l}\text { Drinking } \\
\text { water }\end{array}$ & $0.05 \%$ & $\begin{array}{l}\text { Liquid. Concentrated acidifier: formic, } \\
\text { propionic, sorbic, lactic and citric acids. }\end{array}$ \\
\hline B & $\begin{array}{l}\text { Drinking } \\
\text { water }\end{array}$ & $0.2 \%$ & $\begin{array}{l}\text { Liquid. Propionic acid plus copper sulphate, } \\
\text { terpenes and ammonia. }\end{array}$ \\
\hline C & $\begin{array}{l}\text { Drinking } \\
\text { water }\end{array}$ & $0.3 \%$ & $\begin{array}{l}\text { Liquid. Formic, acetic and sorbic acids, zinc } \\
\text { and cupric acetates, ammonium formate. }\end{array}$ \\
\hline D & $\begin{array}{l}\text { Drinking } \\
\text { water }\end{array}$ & $0.3 \%$ & $\begin{array}{l}\text { Liquid. Synergistic blend of free and } \\
\text { buffered organic acids. }\end{array}$ \\
\hline$E$ & Feed & $0.45 \%$ & $\begin{array}{l}\text { Solid. Multipurpose feed acidification } \\
\text { mixture for swine and poultry feed. }\end{array}$ \\
\hline$F$ & Feed & $0.3 \%$ & $\begin{array}{l}\text { Liquid. Medium chain fatty acid blend for } \\
\text { feed. }\end{array}$ \\
\hline G & Feed & $0.6 \%$ & Solid. Sodium formate and formic acid. \\
\hline $\mathrm{H}$ & Feed & $0.2 \%$ & $\begin{array}{l}\text { Solid. Detergent, organic acids and their } \\
\text { ammonium salts. }\end{array}$ \\
\hline I & Feed & $0.3 \%$ & $\begin{array}{l}\text { Liquid. Organic acids, butyrate and } \\
\text { mannobiose. }\end{array}$ \\
\hline J & Feed & $0.3 \%$ & $\begin{array}{l}\text { Liquid. Propionic, formic and lactic acids, } \\
\text { ammonium formate, flavour and emulsifiers. }\end{array}$ \\
\hline $\mathrm{K}$ & Feed & $0.6 \%$ & $\begin{array}{l}\text { Solid. Formic acid, Ammonium formate, } \\
\text { Ammonium Propionate }\end{array}$ \\
\hline $\mathrm{L}$ & $\begin{array}{l}\text { Feed or } \\
\text { drinking } \\
\text { water }\end{array}$ & $\begin{array}{l}0.8 \% \text { (feed) } \\
0.2 \% \text { (water) }\end{array}$ & $\begin{array}{l}\text { Liquid. Formic acid, Ammonium formate, } \\
\text { Ammonium Propionate }\end{array}$ \\
\hline M & Feed & $0.3 \%$ & $\begin{array}{l}\text { Liquid. Mixture of formalin, propionic acid, } \\
\text { terpenes and surfactant. }\end{array}$ \\
\hline N & Feed & $\begin{array}{l}0.3 \% \text { (active }^{-} \\
\text {ingredients) }\end{array}$ & $\begin{array}{l}\text { Blend of organic acids and flavours } \\
\text { microencapsulated with a lipid matrix. }\end{array}$ \\
\hline O & Feed & $\begin{array}{l}0.1 \% \text { (active }^{-} \\
\text {ingredients) }^{\mathrm{b}}\end{array}$ & $\begin{array}{l}\text { Blend of organic acids and their salts } \\
\text { microencapsulated with a lipid matrix. }\end{array}$ \\
\hline
\end{tabular}

a As recommended by manufacturer; v/v (liquids) or w/v (solids).

b Product is encapsulated; active ingredients were tested as a free powder. 
Table 3: Results of maximum inhibitory dilution and maximum bactericidal dilution determinations using eight test strains of Salmonella

\begin{tabular}{|c|c|c|c|c|c|c|c|c|}
\hline & \multicolumn{4}{|c|}{ Maximum inhibitory dilution (MID) } & \multicolumn{4}{|c|}{ Maximum bactericidal dilution (MBD) } \\
\hline & $\begin{array}{l}\text { Maximum } \\
\text { recommended } \\
\text { concentration (\%) }\end{array}$ & $\begin{array}{l}\text { Predicted } \\
\text { mean } \\
\text { dilution }^{a}\end{array}$ & $\begin{array}{l}95 \% \\
\text { confidence } \\
\text { intervalb }^{b}\end{array}$ & $\begin{array}{l}\text { Multiple } \\
\text { comparisons }^{c}\end{array}$ & $\begin{array}{l}\text { Maximum } \\
\text { recommended } \\
\text { concentration (\%) }\end{array}$ & $\begin{array}{l}\text { Predicted } \\
\text { mean } \\
\text { dilutiona }^{\mathrm{a}}\end{array}$ & $\begin{array}{l}95 \% \\
\text { confidence } \\
\text { interval }^{b}\end{array}$ & $\begin{array}{l}\text { Multiple } \\
\text { comparisons }^{c}\end{array}$ \\
\hline \multicolumn{9}{|c|}{$\begin{array}{l}\text { Water } \\
\text { products }\end{array}$} \\
\hline $\mathrm{B}$ & 0.2 & 637 & $512-793$ & $\alpha$ & 0.2 & 7 & $1-44$ & $\alpha$ \\
\hline $\mathrm{D}$ & 0.3 & 1131 & $892-1435$ & $\beta$ & 0.3 & 69 & $40-119$ & $\alpha \beta$ \\
\hline $\mathrm{C}$ & 0.3 & 1131 & $919-1393$ & $\beta$ & 0.3 & 154 & $94-253$ & $\beta$ \\
\hline$A$ & 0.05 & 1497 & $1240-1807$ & $\beta$ & 0.05 & 1131 & $689-1857$ & Y \\
\hline \multicolumn{9}{|c|}{$\begin{array}{l}\text { Feed } \\
\text { products }\end{array}$} \\
\hline $\mathrm{N}$ & 0.3 & 64 & $51-80$ & A & 0.3 & 7 & $2-30$ & A \\
\hline $\mathrm{O}$ & 0.1 & 64 & $51-80$ & $A$ & 0.1 & 7 & $2-30$ & $A$ \\
\hline $\mathrm{K}$ & 0.6 & 71 & $56-89$ & $A$ & 0.6 & 7 & $2-30$ & $A$ \\
\hline $\mathrm{F}$ & 0.3 & 88 & $72-107$ & $A$ & 0.45 & 47 & $24-92$ & $A, B$ \\
\hline I & 0.3 & 372 & $303-457$ & $\mathrm{~B}$ & 0.3 & 56 & $31-100$ & $A B$ \\
\hline $\mathrm{L}$ & 0.8 & 400 & $327-489$ & B C & 0.8 & 68 & $37-127$ & $A B C$ \\
\hline$E$ & 0.45 & 636 & $511-793$ & C & 0.6 & 119 & $66-213$ & B C D \\
\hline$G$ & 0.6 & 1131 & $894-1432$ & $\mathrm{D}$ & 0.3 & 255 & $142-460$ & $\mathrm{D}$ \\
\hline $\mathrm{J}$ & 0.3 & 1381 & $1118-1705$ & $\mathrm{D}$ & 0.3 & 336 & $188-603$ & $D$ \\
\hline $\mathrm{H}$ & 0.2 & 2506 & $2003-3136$ & $E$ & 0.2 & 1600 & $892-2869$ & $E$ \\
\hline$M$ & 0.3 & 23777 & $19370-29186$ & $\mathrm{~F}$ & 0.3 & 4936 & $2755-8842$ & $E$ \\
\hline
\end{tabular}

a Highest dilution of product associated with inhibition (MID) or abolition (MBD) of bacterial growth.

${ }^{b}$ Not adjusted for multiple comparisons.

c Products in the same column with a letter in common do not differ significantly at $p=0.05$ by Tukeys HSD test. Water products were not compared with feed products. 
Table 4: Reductions in $S$. Enteritidis over time with exposure to organic acid preparations in tap and river water

\begin{tabular}{|c|c|c|c|c|c|c|c|c|}
\hline \multirow[b]{3}{*}{ Product } & \multicolumn{4}{|c|}{ Tap water } & \multicolumn{4}{|c|}{ River water } \\
\hline & \multirow[b]{2}{*}{$\mathrm{pH}^{\mathrm{a}}$} & \multicolumn{3}{|c|}{$\log _{10}$ reduction ${ }^{b}$} & \multirow[b]{2}{*}{$\mathrm{pH}^{\mathrm{a}}$} & \multicolumn{3}{|c|}{$\log _{10}$ reduction ${ }^{b}$} \\
\hline & & $1 \mathrm{hr}$ & $2 \mathrm{hr}$ & $4 \mathrm{hr}$ & & $1 \mathrm{hr}$ & $2 \mathrm{hr}$ & $4 \mathrm{hr}$ \\
\hline A & 3.9 & $>5$ & $>5$ & $>5$ & 3.3 & 1 & 1 & 0 \\
\hline B & 5.1 & 2 & 3 & 3 & 4.8 & 1 & 1 & 2 \\
\hline C & 3.9 & $>5$ & $>5$ & $>5$ & 3.8 & 1 & 1 & 2 \\
\hline D & 3.4 & $>5$ & $>5$ & $>5$ & 3.5 & 2 & 2 & 4 \\
\hline L & 4.9 & 3 & 5 & $>5$ & 4.5 & 1 & 0 & 1 \\
\hline
\end{tabular}

${ }^{a} \mathrm{pH}$ after addition to water of product at manufacturer's maximum recommended concentration, as given in Table 2.

${ }^{b}$ Values are net reductions, after subtraction of any reduction seen in controls without added product.

Table 5: Reduction in $S$. Enteritidis numbers over time with exposure to organic acid preparations mixed with feed or poultry litter

\begin{tabular}{|c|c|c|c|c|}
\hline \multirow[b]{3}{*}{ Product $^{\mathrm{a}}$} & \multicolumn{4}{|c|}{ Salmonella $\log _{10}$ reduction ${ }^{b}$} \\
\hline & \multicolumn{2}{|c|}{ In feed matrix } & \multicolumn{2}{|c|}{ In litter matrix } \\
\hline & after $24 \mathrm{~h}$ & after $7 d$ & after $4 \mathrm{~h}$ & after $8 \mathrm{~h}$ \\
\hline$E$ & 2 & 2 & 1 & 1 \\
\hline $\mathrm{F}$ & 3 & 3 & 1 & 1 \\
\hline G & 1 & 1 & 0 & 0 \\
\hline $\mathrm{H}$ & 1 & 2 & 1 & 0 \\
\hline । & 0 & 1 & 1 & 0 \\
\hline J & 0 & 1 & 0 & 0 \\
\hline K & 0 & 1 & 1 & 1 \\
\hline $\mathrm{L}$ & 1 & 1 & 2 & 6 \\
\hline M & $>3$ & $>3$ & 3 & 6 \\
\hline N & 0 & 0 & 1 & 0 \\
\hline O & 1 & 1 & 0 & 0 \\
\hline
\end{tabular}

a Products used at concentrations given in Table 2.

b Values are net reductions, after subtraction of any reduction seen in controls without added product. 
Table 6: Reductions in $S$. Enteritidis over time with exposure to organic acid preparations mixed with poultry caecal and crop contents

\begin{tabular}{|c|c|c|c|c|c|c|c|c|c|}
\hline \multirow{3}{*}{$\begin{array}{l}\text { Test } \\
\text { preparation }^{a}\end{array}$} & \multirow{3}{*}{$\begin{array}{l}\text { Run/sub } \\
\text {-sample }\end{array}$} & \multicolumn{8}{|c|}{ Salmonella $\log _{10}$ reduction after specified time } \\
\hline & & \multicolumn{3}{|c|}{ Caecal contents } & \multicolumn{5}{|c|}{ Crop contents } \\
\hline & & $1 \mathrm{~h}$ & $4 \mathrm{~h}$ & $9 \mathrm{~h}$ & $1 \mathrm{~h}$ & $2 \mathrm{~h}$ & $4 \mathrm{~h}$ & $5 \mathrm{~h}$ & $8 \mathrm{~h}$ \\
\hline \multicolumn{10}{|l|}{ Water products } \\
\hline A & a & & 1 & 1 & 1 & & 5 & & $>5$ \\
\hline $\mathrm{C}$ & a & & 1 & 1 & 4 & & $>5$ & & $>5$ \\
\hline \multirow[t]{4}{*}{$\mathrm{D}$} & a & & 0 & 1 & 5 & & $>5$ & & $>5$ \\
\hline & $\mathrm{b} / 1$ & & & & $>5$ & $>5$ & & $>5$ & \\
\hline & $b / 2$ & & & & $>5$ & $>5$ & & $>5$ & \\
\hline & $\mathrm{b} / 3$ & & & & $>5$ & $>5$ & & $>5$ & \\
\hline \multicolumn{10}{|l|}{ Feed products } \\
\hline \multirow[t]{4}{*}{ E } & a & 1 & 0 & 1 & 3 & & 4 & & $>6$ \\
\hline & $\mathrm{b} / 1$ & & & & $>5$ & $>5$ & & $>5$ & \\
\hline & $b / 2$ & & & & $>5$ & $>5$ & & $>5$ & \\
\hline & $b / 3$ & & & & 4 & 5 & & $>5$ & \\
\hline \multirow[t]{4}{*}{$\mathrm{F}$} & $a$ & 2 & 4 & 6 & $>6$ & & $>6$ & & $>6$ \\
\hline & $b / 1$ & & & & $>5$ & $>5$ & & $>5$ & \\
\hline & $b / 2$ & & & & $>5$ & $>5$ & & $>5$ & \\
\hline & $b / 3$ & & & & $>5$ & $>5$ & & $>5$ & \\
\hline G & a & 1 & 1 & 2 & 3 & & $>6$ & & $>6$ \\
\hline $\mathrm{H}$ & a & 0 & 1 & 2 & 2 & & $>6$ & & $>6$ \\
\hline 1 & a & 0 & 1 & 2 & 2 & & 3 & & $>6$ \\
\hline$J$ & a & 2 & 1 & 2 & 1 & & $>6$ & & $>6$ \\
\hline $\mathrm{K}$ & a & 1 & 0 & 1 & 1 & & 1 & & 5 \\
\hline $\mathrm{L}$ & a & 2 & 0 & 2 & 2 & & $>6$ & & $>6$ \\
\hline \multirow[t]{4}{*}{$M$} & a & $>6$ & $>6$ & $>6$ & $>6$ & & $>6$ & & $>6$ \\
\hline & $\mathrm{b} / 1$ & & & & $>5$ & $>5$ & & $>5$ & \\
\hline & $\mathrm{b} / 2$ & & & & $>5$ & $>5$ & & $>5$ & \\
\hline & $b / 3$ & & & & $>5$ & $>5$ & & $>5$ & \\
\hline $\mathrm{N}$ & a & 1 & 1 & 2 & 1 & & 2 & & $>6$ \\
\hline O & a & 1 & 1 & 2 & 1 & & 2 & & 6 \\
\hline \multirow[t]{4}{*}{ Water (control) ${ }^{\mathrm{b}}$} & a & 0 & 1 & 2 & 0 & & 1 & & 4 \\
\hline & $\mathrm{b} / 1$ & & & & 0 & 2 & & 4 & \\
\hline & $\mathrm{b} / 2$ & & & & 1 & 1 & & $>5$ & \\
\hline & $b / 3$ & & & & 0 & 3 & & 5 & \\
\hline
\end{tabular}

a Products used at concentrations given in Table 2.

b Organic acid product substituted by $0.3 \%$ v/v water. 
Figure legends

Figure 1: Effect on inoculated Salmonella of organic acid product D $(0.3 \%)$ in tap water.

Figure 2: Effect on inoculated Salmonella of organic acid product $\mathrm{D}(0.3 \%)$ in tap and bottled water, at room temperature $\left(14-15^{\circ} \mathrm{C}\right)$. 